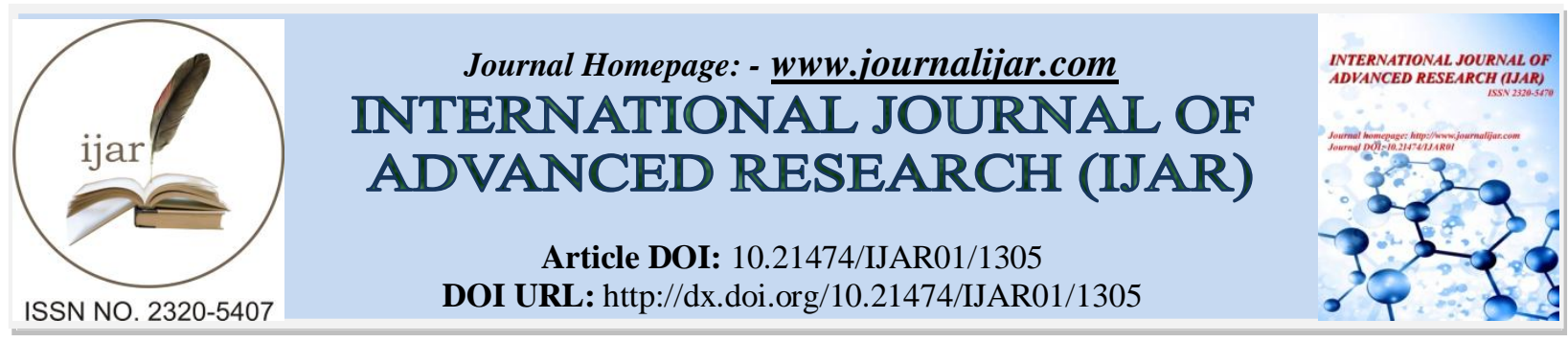

RESEARCH ARTICLE

\title{
SYNTHESIS, CHARACTERIZATION, ANTI-INFLAMMATORY, ANTIMICROBIAL AND DNA BINDING PROPERTIES OF Co(II). Ni(II), Cd(II) AND Cu(II) COMPLEXES WITH SCHIFF BASE.
}

*Asha M S ${ }^{1}$, Othbert Pinto ${ }^{1}$, Nagendra Murthy V N ${ }^{1}$, Varadha Raj ${ }^{1}$ and Delarasoltanesmaeili ${ }^{2}$.

1. St. Philomena's College, Bannimantap, Mysore, Karnataka, India.

2. Department of Studies in Biotechnology, JSS College of Arts, Commerce and Science, Ooty road, Mysore, Karnataka, India.

\section{Manuscript Info}

Manuscript History

Received: 12 June 2016

Final Accepted: 18 July 2016

Published: August 2016

Key words:-

Benzophenone, o-phenylenediamine,

metal complex, anti-inflammatory,

antimicrobial, DNA binding properties.

\section{Abstract}

The meal complexes of $\mathrm{Co}(\mathrm{II}), \mathrm{Ni}(\mathrm{II}), \mathrm{Cu}(\mathrm{II}), \mathrm{Cd}(\mathrm{II})$ and $\mathrm{Zn}$ (II) derived from hydroxyl benzophenone and o-phenylenediamine have been synthesised and characterized by elemental analysis, ${ }^{1} \mathrm{H}$ NMR, FT-IR, UV-visible, Mass spectroscopy, molar conductometry, magnetic susceptibility and thermal analysis study. The FT-IR spectral study reveals that the ligand behaves as a dibasic tetradentate ligand with $\mathrm{N}_{2} \mathrm{O}_{2}$ donor atoms sequence towards central metal ion. The physico-chemical study reveals octahedral geometry for the complexes. The results show the formation of 2:1(ligand: metal chloride) complexes with amine and screened for anti-inflammatory, antimicrobial, DNA binding properties.

Copy Right, IJAR, 2016,. All rights reserved.

\section{Introduction:-}

During the past two decades, considerable attention has been paid to the chemistry of metal complexes containing nitrogen and other donor ${ }^{1}$. The tetradentate Schiff base complexes are well known to form stable complexes, where coordination takes place through the $\mathrm{N}_{2} \mathrm{O}_{2}$ donor set ${ }^{2-4}$. N, O- bidentate and $\mathrm{N}_{2} \mathrm{O}_{2}$-tetradentate ligands (soft and hard donor) possess many, advantages such as facile approach, relative tolerance, readily adjusted ancillary ligands, and tunable steric and electronic coordination environments on the metal center ${ }^{5}$. This may be attributed to their potential application in many fields such as oxidation catalysis ${ }^{6}$ and electrochemistry ${ }^{7}$. Transition metals are involved in many biological processes which are essential to life process. The metals can coordinate with $\mathrm{O}-$ or Nterminals from proteins in a variety of models and play a crucial role in the conformation and function of biological macromolecules $^{8,9}$. This paper reports the synthesis, characterization, thermal and biological studies of metal(II) complexes derived from the reaction of hydroxyl benzophenone and o-phenylenediamine in alcohol.

\section{Experimental section:- \\ Materials and Methods:-}

All the chemicals used in the preparation of Schiff base and its metal complexes were of AR grade. A Perkin-Elmer CHN analyzer (model 2400) was used for $\mathrm{C}, \mathrm{H}$ and $\mathrm{N}$ analyses. The room temperature molar conductance was determined using a Century digital conductivity meter (model cc 601) with a dip type cell and a smooth platinum electrode. The electronic absorption spectra of the complexes were recorded as dilute solutions on a Shimadzu 160A/240A UV-visible spectrophotometer. The ${ }^{1} \mathrm{H}$ NMR spectra were recorded using Bruker DRX 400 spectrometer at $400 \mathrm{MHz}$ with TMS as the internal standard. Mass spectra were obtained with a VG70-70H 
spectrophotometer. The infrared spectra of the solid samples were recorded in the range 4000-500 $\mathrm{cm}^{-1}$ on a PerkinElmer 597/1650 spectrophotometer using $\mathrm{KBr}$ pellets. The magnetic moments were measured out using gouy balance. Purity of the compound was checked by TLC $^{10}$.
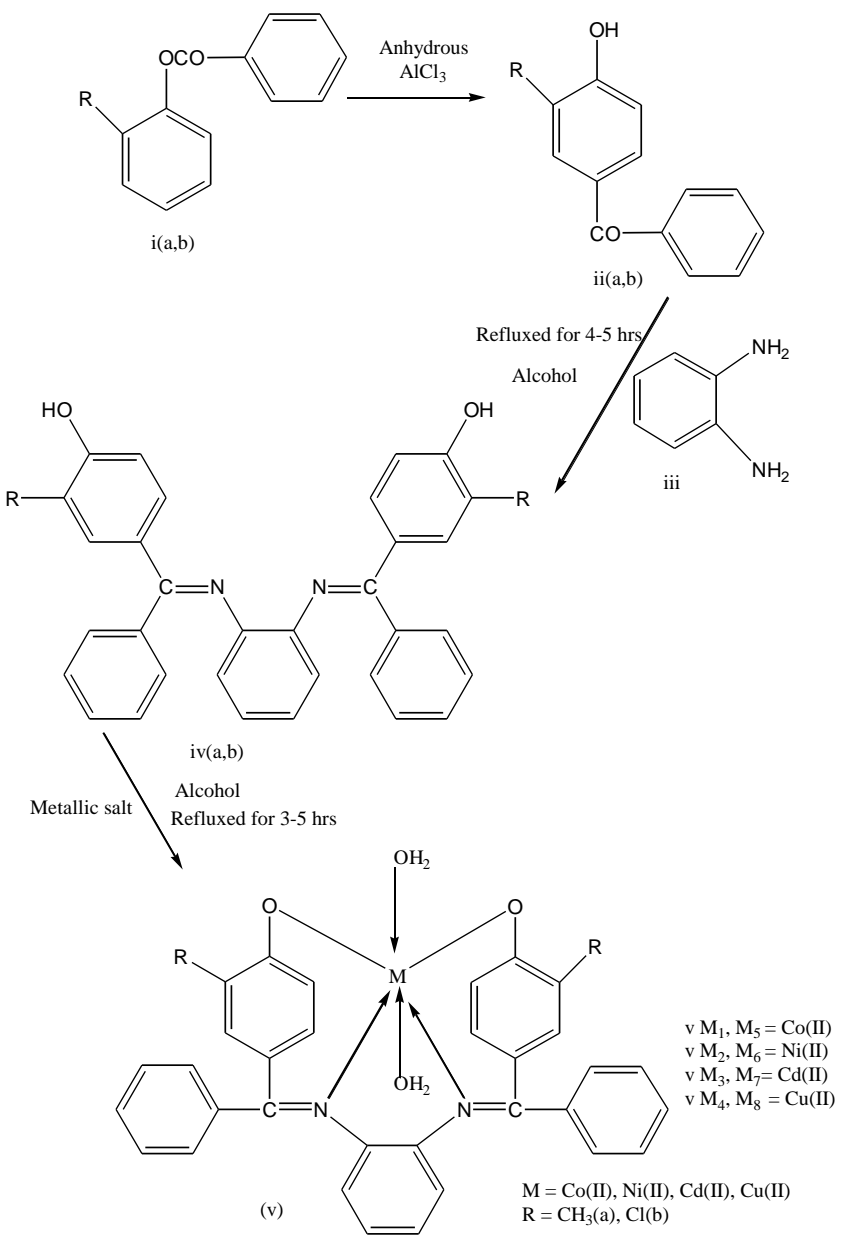

Synthesis of Schiff base ligands and their metal complexes

General procedure for the preparation of Schiff Bases (iva,b):-

A mixture of o-phenylenediamine (iii) and substituted hydroxylbenzophenone (iiab) in 1:2 molar ratio in methanol was refluxed with constant stirring. This condensation reaction was carried by using 3 drops of acetic acid for 5 hours. The formed water was removed from the reaction mixture by using sodium sulphate as dehydrating agent. After completion of the reaction, the mixture was reduced to half of its original volume and kept aside at room temperature. The white precipitate (iva,b) was formed on slow evaporation. This was filtered off and washed with ethanol. The product was recrystallized from hot ethanol and stored over anhydrous calcium chloride ${ }^{11}$.

iva: Yield 85\%; M.p. $167^{\circ} \mathrm{C}$; IR (Nujol): (C=N) 1665, (O-H) $3505 \mathrm{~cm}^{-1},{ }^{1} \mathrm{H}$ NMR (DMSO): $\delta$ 6.9-8.1 (m, 20H, Ar$\mathrm{H}$ ), 10.7 (bs, $2 \mathrm{H}$, $-\mathrm{OH}$ phenolic). MS: m/z 536 Anal.Calcd.for $\mathrm{C}_{32} \mathrm{H}_{22} \mathrm{Cl}_{2} \mathrm{~N}_{2} \mathrm{O}_{2}$ : C, 71.51; H, 4.13; N, 5.21. Found: C, $71.63 ; \mathrm{H}, 4.22 ; \mathrm{N}, 5.62 \%$.

ivb: Yield 79\%; M.p. $156^{\circ} \mathrm{C}$; IR (Nujol): (C=N) 1668, (O-H) $3502 \mathrm{~cm}^{-1},{ }^{1} \mathrm{H}$ NMR (DMSO): $\delta$ 6.7-7.9 (m, 26H, ArH), 11.5 (bs, $2 \mathrm{H}$, $-\mathrm{OH}$ phenolic). MS: m/z 496 Anal.Calcd.for $\mathrm{C}_{34} \mathrm{H}_{26} \mathrm{~N}_{2} \mathrm{O}_{2}$ : C, 82.20; H, 5.24; N, 5.61. Found: C, $82.16 ; \mathrm{H}, 5.30 ; \mathrm{N}, 5.55 \%$. 
General procedure for the preparation of complexes $\left(\mathrm{vM}_{1}-\mathrm{M}_{8}\right)$ :-

A solution of ligand (ivab) and cobalt(II) chloride hexa hydrate in 1:1 molar ratio in ethanol was refluxed for 6 hours. The resulting solution was reduced to half of its volume and kept aside. On standing, the obtained solid product was filtered off and washed with water and ethanol. The product $\left(\mathbf{v} \mathbf{M}_{\mathbf{1}}-\mathbf{M}_{\mathbf{8}}\right)$ was recrystallized from a mixture of chloroform and ethanol (3:1) and stored over anhydrous calcium chloride ${ }^{11}$.

$\mathrm{vM}_{1}$ : Yield 60\%; M.p. $>250^{\circ} \mathrm{C}$; IR (Nujol): (M-O) 462, (M-N) 527, (C=N) $1645 \mathrm{~cm}^{-1}\left(\mathrm{H}_{2} \mathrm{O}\right) 3562 \mathrm{~cm}^{-1} . \mathrm{MS}: \mathrm{m} / \mathrm{z}$ 628; Anal.Calcd.for $\mathrm{C}_{32} \mathrm{H}_{20} \mathrm{Cl}_{2} \mathrm{~N}_{2} \mathrm{O}_{2} \mathrm{Co}\left(\mathrm{H}_{2} \mathrm{O}\right)_{2}$ (628): C, 61.14; H, 3.18; N, 4.45. Found: C, 61.23; H, 3.10; $\mathrm{N}, 4.73 \%$. Molar conductance: 18.9, Magnetic moment: $4.50 \mathrm{~B} \mathrm{M}$.

$\mathrm{vM}_{2}$ : Yield 65\%; M.p. >250 ${ }^{\circ}$; IR (Nujol): (M-O) 470, (M-N) 515, (C=N) $1652 \mathrm{~cm}^{-1}\left(\mathrm{H}_{2} \mathrm{O}\right) 3570 \mathrm{~cm}^{-1}$. MS: m/z 628; Anal.Calcd.for $\mathrm{C}_{32} \mathrm{H}_{20} \mathrm{Cl}_{2} \mathrm{~N}_{2} \mathrm{O}_{2} \mathrm{Ni}\left(\mathrm{H}_{2} \mathrm{O}\right)_{2}$ (628): C, 61.12; H, 3.17; N, 4.28 Found: 61.02; H, 3.07; N, 4.35\%. Molar conductance: 16.2, Magnetic moment: $3.11 \mathrm{~B} \mathrm{M}$.

$\mathrm{vM}_{3}$ : Yield 60\%; M.p. $>250^{\circ} \mathrm{C}$; IR (Nujol): (M-O) 490, (M-N) 560, $(\mathrm{C}=\mathrm{N}) 1650 \mathrm{~cm}^{-1}\left(\mathrm{H}_{2} \mathrm{O}\right) 3557 \mathrm{~cm}^{-1} . \mathrm{MS}: \mathrm{m} / \mathrm{z}$ 682; Anal.Calcd.for $\mathrm{C}_{32} \mathrm{H}_{20} \mathrm{Cl}_{2} \mathrm{~N}_{2} \mathrm{O}_{2} \mathrm{Cd}\left(\mathrm{H}_{2} \mathrm{O}\right)_{2}$ (682): C, 56.30; H, 2.93; N, 4.10. Found: C, 56.45; H, 2.79; N, 4.52\%. Molar conductance: $14.2 \mathrm{~B} \mathrm{M}$.

$\mathrm{vM}_{4}$ : Yield 62\%; M.p. >250 ${ }^{\circ}$; IR (Nujol): (M-O) 477, (M-N) 540, (C=N) $1651 \mathrm{~cm}^{-1}\left(\mathrm{H}_{2} \mathrm{O}\right) 3565 \mathrm{~cm}^{-1}$. MS: m/z 632; Anal.Calcd.for $\mathrm{C}_{32} \mathrm{H}_{20} \mathrm{Cl}_{2} \mathrm{~N}_{2} \mathrm{O}_{2} \mathrm{Cu}\left(\mathrm{H}_{2} \mathrm{O}\right)_{2}$ (632): C, 60.70; H, 3.16; N, 4.43 Found: C, 60.04; H, 3.08; N, 4.03\%. Molar conductance: 18.3, Magnetic moment: $1.92 \mathrm{~B} \mathrm{M}$.

vM$_{5}$ : Yield 65\%; M.p. >250 ${ }^{\circ}$; IR (Nujol): (M-O) 463, (M-N) 505, (C=N) $1642 \mathrm{~cm}^{-1}\left(\mathrm{H}_{2} \mathrm{O}\right) 3555 \mathrm{~cm}^{-1}$. MS: m/z 588; Anal.Calcd.for $\mathrm{C}_{34} \mathrm{H}_{24} \mathrm{~N}_{2} \mathrm{O}_{2} \mathrm{Co}\left(\mathrm{H}_{2} \mathrm{O}\right)_{2}$ (588): C, 69.28; H, 4.07; N, 4.75. Found: C, 69.44; H, 4.18; N, 4.65\%. Molar conductance: 19.6, Magnetic moment: 4.55 B M.

ivM $_{6}$ : Yield 62\%; M.p. >250 C; IR (Nujol): (M-O) 470, (M-N) 520, (C=N) $1634 \mathrm{~cm}^{-1}\left(\mathrm{H}_{2} \mathrm{O}\right) 3560 \mathrm{~cm}^{-1}$. MS: m/z 588; Anal.Calcd.for $\mathrm{C}_{34} \mathrm{H}_{24} \mathrm{~N}_{2} \mathrm{O}_{2} \mathrm{Ni}\left(\mathrm{H}_{2} \mathrm{O}\right)_{2}$ (588): C, 69.01; H, 4.02; N, 4.58. Found: C, 69.11; H, 4.10; N, 4.35\%. Molar conductance: 16.9, Magnetic moment: $3.02 \mathrm{~B} \mathrm{M}$.

$\mathrm{vM}_{7}$ : Yield 60\%; M.p. >250 $0^{\circ}$; IR (Nujol): (M-O) 495, (M-N) 590, (C=N) $1650 \mathrm{~cm}^{-1}\left(\mathrm{H}_{2} \mathrm{O}\right) 3560 \mathrm{~cm}^{-1} . \mathrm{MS}: \mathrm{m} / \mathrm{z}$ 640; Anal.Calcd.for $\mathrm{C}_{34} \mathrm{H}_{24} \mathrm{~N}_{2} \mathrm{O}_{2} \mathrm{Cd}\left(\mathrm{H}_{2} \mathrm{O}\right)_{2}$ (640): C, 63.75; H, 3.75; N, 4.37. Found: C, 63.70; H, 3.72; N, 4.28\%. Molar conductance: 14.5 .

vM$_{8}$ : Yield 61\%; M.p. $>250^{\circ} \mathrm{C}$; IR (Nujol): (M-O) 500, (M-N) 575, (C=N) $1653 \mathrm{~cm}^{-1}\left(\mathrm{H}_{2} \mathrm{O}\right) 3550 \mathrm{~cm}^{-1}$. MS: m/z 592; Anal.Calcd.for $\mathrm{C}_{34} \mathrm{H}_{24} \mathrm{~N}_{2} \mathrm{O}_{2} \mathrm{Cu}\left(\mathrm{H}_{2} \mathrm{O}\right)_{2}$ (592): C, 68.91; H, 4.05; N, 4.72. Found: C, 68.75; H, 4.15; N, 4.83\%. Molar conductance: 19.8. Magnetic moment: $1.90 \mathrm{~B} \mathrm{M}$.

\section{Biology:-}

Materials and Methods:-

Hemolysing buffer [0.85\% $\mathrm{NH}_{4} \mathrm{Cl}, 10 \mathrm{mM}$ Tris $\mathrm{pH}$ 7.4]. Calf thymus DNA was purchased from Genie Company. Viperarusselli venom was obtained from IRULA snake catchers (Madras). Micro organisms were procured from university of Mysore, Department of Microbiology. All other chemicals are purchased from Sisco Research laboratory, Mumbai, India. All reagents were of analytical grade.

\section{Antimicrobial Evaluation:-}

The newly synthesized Schiff- base derivatives (iva,b, $\mathrm{vM}_{1}-\mathrm{M}_{8}$ ) were evaluated in vitro for antibacterial activity against Staphylococcus aureus and Stepotococcusepidermidis as examples of Gram-positive bacteria and Listeria monocytogenes and Escherichia coli as examples of Gram-negative bacteria. They were also evaluated in vitro for their antifungal activity against Candida albicans. Inhibition zone diameter (IZD) in $\mathrm{cm}$ was used as criterion for the antimicrobial activity using agar diffusion well method. Gentamycin and Flucanazole were used as reference drugs for antibacterial and antifungal activity respectively. Microbes were grown in Nutrient Broth (NB, Merck) medium at $37^{\circ} \mathrm{C}$ for $24 \mathrm{~h}$. The bacterial number in the final inoculums was adjusted to $10^{6} \mathrm{CFU} / \mathrm{ml}$. A bacterial lawn was prepared by pouring $0.1 \mathrm{ml}$ of bacterial suspension onto each plate of Nutrient Agar medium (NA, Merck), spread by a sterile cotton swab, and allowed to remain in contact for $1 \mathrm{~min}$. Schiff base derivatives of different concentrations $(20 \mu \mathrm{g}, 40 \mu \mathrm{g}, 80 \mu \mathrm{g}, 100 \mu \mathrm{g})$ were prepared in order to impregnate the paper discs. The sterile filter 
paper discs containing Schiff- base derivatives (6-mm diameter) were then placed on the bacterial lawn. The Petri dishes were subsequently incubated at $37^{\circ} \mathrm{C}$ for $24 \mathrm{~h}$ and the inhibition zone around each disc was measured in $\mathrm{cm}$.

\section{Anti inflammatory activity:- Indirect Haemolytic assay of PLA:-}

Protein concentration in the venom was calculated, using bovine serum albumin fraction $\mathrm{V}(0-75 \mu \mathrm{g})$. A semi quantitative indirect haemolytic assay was employed. Briefly, packed human erythrocytes, egg yolk and phosphate buffer saline was mixed $(1: 1: 8 \mathrm{~V} / \mathrm{V})$. $1 \mathrm{ml}$ of this suspension was incubated with $60 \mu \mathrm{g}$ enzyme for $10 \mathrm{~min}$ at $37^{0} \mathrm{C}$. The reaction was stopped by adding $9 \mathrm{ml}$ of cold phosphate buffer saline and centrifuged at $4^{0} \mathrm{C}$ for $10 \mathrm{~min}$ at $800 \mathrm{Xg}$. The amount of haemoglobin released in the supernatant was measured at $540 \mathrm{~nm}$. The assay was also carried out in the presence of various concentrations 200-1000ng/ml. Enzyme and substrate without the inhibitor served as control.

\section{DNA Binding and chelating assay using Calf thymus DNA:-}

For the gel electrophoresis study, calf thymus DNA $(20 \mu \mathrm{g})$ was treated with the $10 \mu \mathrm{g}$ of Schiff base derivatives and incubated for 30 minuts in $40 \mathrm{mM}$ Tris-buffer ( $\mathrm{pH} 8.3$ ). The samples were electrophoresed for 3 hours at $50 \mathrm{~V}$ on a $1 \%$ agarose gel in Tris-acetic acid-EDTA buffer. The gel was stained with $0.5 \mu \mathrm{g}$ of ethidium bromide. Photographed under UV light.

\section{Cell viability assay:-}

Tryphan blue exclusion test is based on the principle that living cell membrane has the ability to prevent the entry of the dye, hence they remain unstained and can be easily distinguished from the dead cell which take up the dye. The percentage of viable cells was determined by diluting the isolated lymphocytes with $0.4 \%$ tryphan blue, mixed and loaded into haemocytometer. The viable cells were counted under microscope and $\%$ of viability was calculated.

\section{Isolation of Human Peripheral Lymphocytes:-}

$10 \mathrm{ml}$ of blood and $2 \mathrm{ml}$ of ACD were mixed, it is incubated with 4 volumes of haemolysing buffer at $4^{0} \mathrm{C}$ for 30 minutes centrifuged at $1500 \mathrm{rpm}$ for $12 \mathrm{~min}$ at $4^{0} \mathrm{C}$, pellet was subjected to10ml lysing buffer, centrifuged at 1500 rpm for $12 \mathrm{~min}$, pellet was washed with HBSS solution, suspended in $2 \mathrm{ml}$ of same solution.

\section{Cell Viability by dye exclusion method:-}

Lymphocytes $\left(10 \times 10^{6}\right)$ suspended in $1 \mathrm{ml}$ of HBSS were treated with Schiff base derivatives $(5 \mu \mathrm{l}-500 \mathrm{ng})$ dissolved in DMF and incubated for 60 minutes in a shaking water bath at $37^{\circ} \mathrm{C}$. At the end of incubation, aliquot of cells was taken for viability assay by tryphan blue exclusion method. Stained and stainless cells were counted. \% of viable cell calculated by using the following formula

$\%$ of viable cells $=$ number of living cells/Total number of cells $\times 100$

\section{Result and discussion:-}

\section{Chemistry:-}

Benzoylation of phenols ${ }^{12}$, Fries rearrangement used to convert a phenyl ester to an ortho- and para-hydroxy aryl ketone iia,b.

Based on these information ligands (iva,b) were achieved by condensation reaction of substituted hydroxybenzophenone (ii) with o-phenylenediamine in presence of methanol by adopting the above method. Benzoyl phenol based cobalt(II), nickel(II), cadmium(II) and copper(II) complexes were synthesised using respective salts and organic ligands. All the complexes $\mathbf{v M}_{\mathbf{1}}-\mathbf{M}_{\mathbf{8}}$ are colored, stable at room temperature, soluble in DMSO and melt with decomposition above $250^{\circ} \mathrm{C}$. Unfortunately, our efforts to obtain single crystals of complexes were not successful. Therefore the ligands and their complexes were characterized on the basis of elemental analysis, ${ }^{1} \mathrm{H}$ NMR, IR, magnetic susceptibility measurement, electronic spectra data, colours, melting point, partial elemental analyses and molar conductivities.

The elemental analysis of the compounds is in good agreement with their proposed formulae and the molar conductance of all the complexes in DMSO shows that they are non-electrolytes ${ }^{13}$. Thin layer chromatographic analysis was monitored for the progress of the reactions. The yield, elemental analysis and molar conductance data of metal complexes are presented in Table 1.1 and 1.2. 


\section{FT IR Spectra:-}

The IR spectra of the complexes were compared with those of the free ligands in order to determine the coordination sites that may be involved in chelation. There were some guide peaks in the spectra of the ligands, which were helpful in achieving this goal. The IR spectra of the ligands (iva,b) show a very strong band at $3505 \mathrm{~cm}^{-1}$ and 3502 $\mathrm{cm}^{-1}$ was assigned to in-plane bending $(\mathrm{O}-\mathrm{H})$ vibration. The absence of $(\mathrm{O}-\mathrm{H})$ stretching and $\mathrm{v}(\mathrm{O}-\mathrm{H})$ vibration in the spectra of the complexes indicated deprotonation of the $-\mathrm{OH}$ groups ${ }^{14}$. The strong band observed in the region 1665 and $1668 \mathrm{~cm}^{-1}$ in the ligands (iva,b) assigned to $\mathrm{C}=\mathrm{N}$ stretching. The complexes show a strong band at 1634-1653 $\mathrm{cm}^{-1}\left(\mathbf{v M}_{\mathbf{1}}-\mathbf{M}_{\mathbf{8}}\right)$ representing the $\mathrm{C}=\mathrm{N}$ stretching moiety. This band is shifted to a lower frequency by $\sim 15-26 \mathrm{~cm}^{-1}$, as compared to the corresponding ligands indicating that the azomethine nitrogen of the $\mathrm{C}=\mathrm{N}$ group has participated in coordination ${ }^{15}$. This can be ascribed to the withdrawn of electron density from the nitrogen atom owing to coordination. The phenolic $\mathrm{v}(\mathrm{O}-\mathrm{H})$ band is shifted from 3505 (iva) and 3502 (ivb) to 1267-1278 (vM $\left.\mathbf{M}_{\mathbf{1}}-\mathbf{M}_{\mathbf{8}}\right)$ as a consequence of the delocalization of double bond in chelate rings that has increased the bond order of the phenolic $\mathrm{C}-\mathrm{O}$. The phenolic oxygen, after the loss of $\mathrm{O}-\mathrm{H}$ proton gets coordinated to the metal. This is supported by shift in the stretching frequency of $\mathrm{v}(\mathrm{C}-\mathrm{O})$ to lower wave number from its position in the free ligand ${ }^{16}$. In addition all the complexes showed additional weak to medium intensity bands in the region new 460-500 and $520-590 \mathrm{~cm}^{-1}\left(\mathbf{v M}_{\mathbf{1}^{-}}\right.$ $\mathbf{M}_{8}$ ) which were absent in the spectra of ligand, these can be attributed to $\mathrm{v}(\mathrm{M}-\mathrm{O})$ and $\mathrm{v}(\mathrm{M}-\mathrm{N})$ respectively ${ }^{17-19}$. The IR spectra showed a strong band in $3550-3575 \mathrm{~cm}^{-1}$ region $\left(\mathbf{v M}_{\mathbf{1}}\right.$-ivM $\left.\mathbf{8}\right)$, suggesting the presence of coordinated water.

\section{${ }^{1}$ H NMR Spectra:-}

The ${ }^{1} \mathrm{H}$ NMR spectra of ligands and their complexes re-recorded in DMSO revealed the formation of the complexes from their ligands. The proton NMR spectrum of the Schiff base ligand iva shows singlet peak at $10.7 \mathrm{ppm}$ which corresponds to the two phenolic-OH groups which is absent in the spectrum of $\mathrm{Cd}(\mathrm{II})$ complex. This indicates that the deprotonated phenolic-O atom is involved in chelation. Both the ligand and $\mathrm{Cd}(\mathrm{II})$ complex show a group of multiplet (6.9-8.1 and 6.6-7.4 ppm). The presence of a peak in the region $4.7 \mathrm{ppm}$ reveals the presence of coordinated water molecules in the complex.

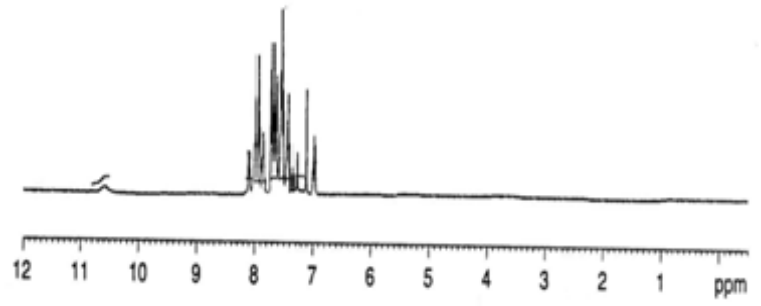

Figure 1.1:- ${ }^{1} \mathrm{H}$ NMR spectrum of ligand iva

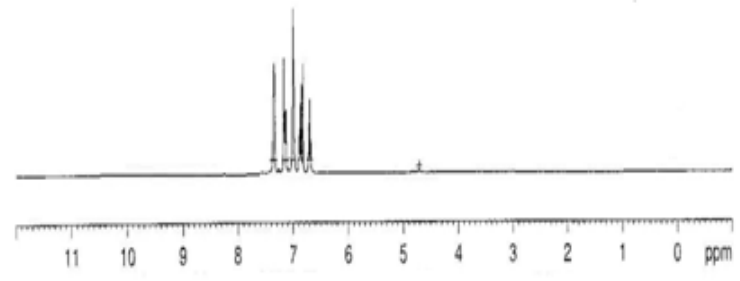

Figure 1.2:- ${ }^{1} \mathrm{H}$ NMR spectrum of $\mathrm{Cd}(\mathrm{II})$ complex $\mathrm{vM}_{3}$

\section{Magnetic Measurements and Electronic Spectra:-}

The magnetic moment of the complexes were measured at room temperature. The electronic spectra of the Schiff base ligands and their $\mathrm{Co}(\mathrm{II}), \mathrm{Ni}(\mathrm{II}), \mathrm{Cd}(\mathrm{II})$ and $\mathrm{Cu}(\mathrm{II})$, complexes have been measured in DMF solution between 200-1800 $\mathrm{nm}$ at room temperature. The electronic absorption spectra are often very helpful for structural investigation. The electronic spectral measurements were used for assigning the geometry of metal ions in the complexes based on the positions and number of $\mathrm{d}-\mathrm{d}$ transition peaks. Magnetic properties arise from the spin and orbital angular momentum of the electrons contained in a compound.

In the spectra of the Schiff base ligands the absorption band observed at 275-293 nm were assigned to a $\pi \rightarrow \pi^{*}$ transition and the band at $355-398 \mathrm{~nm}$ were assigned due to $\mathrm{n} \rightarrow \pi^{*}$ transition associated with the azomethine chromophore $(-\mathrm{C}=\mathrm{N})$. The new bands in complexes near $457-515 \mathrm{~nm}$ can be assigned to $\mathrm{L} \rightarrow \mathrm{M}$ charge transfer band.

The magnetic moment of the complexes were measured at room temperature. The magnetic moment of the cobalt (II) lay in the range 4.50 and $4.55 \mathrm{BM}$ (ivM $\mathbf{M}_{\mathbf{1}}$ and $\mathbf{i v M}_{5}$ ) which corresponds to 3 unpaired electrons. The solution

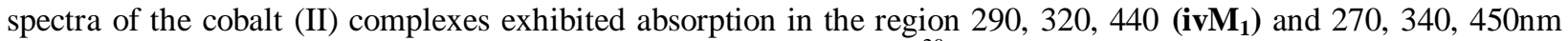
(ivM). The spectra resemble that reported for octahedral complex ${ }^{20}$. Thus the various bands can be assigned to: ${ }^{4} \mathrm{~T}_{1} \mathrm{~g} \rightarrow{ }^{4} \mathrm{~T}_{2} \mathrm{~g},{ }^{4} \mathrm{~T}_{1} \mathrm{~g} \rightarrow{ }^{4} \mathrm{~A}_{2} \mathrm{~g},{ }^{4} \mathrm{~T}_{1} \mathrm{~g} \rightarrow{ }^{4} \mathrm{~T}_{1} \mathrm{~g}$. 
The magnetic moment of the nickel (II) lay in the range 3.11 and $3.02 \mathrm{BM}\left(\mathbf{v M}_{\mathbf{2}}\right.$ and $\left.\mathbf{v M}_{\mathbf{6}}\right)$ which corresponds to 2 unpaired electrons. The solution spectra of the nickel (II) complexes exhibited absorption in the region 330, 380, 420, $470\left(\mathbf{i v M}_{2}\right)$ and 350, 375, 480, $490 \mathrm{~nm}\left(\mathbf{i v M}_{6}\right)$. The spectra resemble that reported for octahedral complex. Thus the various bands can be assigned to: ${ }^{4} \mathrm{~T}_{1} \mathrm{~g} \rightarrow{ }^{4} \mathrm{~T}_{2} \mathrm{~g},{ }^{4} \mathrm{~T}_{1} \mathrm{~g} \rightarrow{ }^{4} \mathrm{~A}_{2} \mathrm{~g},{ }^{4} \mathrm{~T}_{1} \mathrm{~g} \rightarrow{ }^{4} \mathrm{~T}_{1} \mathrm{~g}$ and $\mathrm{L} \rightarrow \mathrm{M}$ charge transfer respectively.

The observed magnetic moment of the $\mathrm{Cu}$ (II) complexes are 1.92 and $1.90 \mathrm{BM}\left(\mathbf{v M}_{\mathbf{4}}\right.$ and $\left.\mathbf{v M}_{\mathbf{8}}\right)$ which confirms the octahedral structure of this complex ${ }^{21-23}$. For octahedral $\mathrm{Cu}(\mathrm{II})$ complexes, the expected transition is assigned to ${ }^{2} \mathrm{Eg}$ $\rightarrow{ }^{2} \mathrm{~T}_{2} \mathrm{~g}$ transition. Due to Jahn-Teller distortions, $\mathrm{Cu}(\mathrm{II})$ complexes give a broad absorption at 615 and $695 \mathrm{~nm}$ $\left(\mathbf{v M}_{4}\right.$ and $\left.\mathbf{v} \mathbf{M}_{8}\right)$.

$\mathrm{Cd}(\mathrm{II})$ ion with $\mathrm{d}^{10}$ electronic configuration permits a wide range of symmetries and coordination numbers. Since $\mathrm{d}^{10}$ configuration affords no crystal field stabilization, the stereochemistry of a particular compound depends on the size and polarizing power of the $\mathrm{M}$ (II) cation and the steric requirement of the ligands and have no $\mathrm{d}-\mathrm{d}$ transition and is diamagnetic.

Analytical, conductance and magnetic moment data of compound.

Table 1:-

\begin{tabular}{|c|c|c|c|c|c|c|}
\hline \multirow[t]{2}{*}{ Compound (Colour) } & \multirow{2}{*}{$\begin{array}{l}\text { M.pt. } \\
\left({ }^{0} \mathrm{C}\right)\end{array}$} & \multirow{2}{*}{$\begin{array}{l}\text { Yield } \\
(\%)\end{array}$} & \multicolumn{3}{|c|}{ Found (Calc.) \% } & \multirow{2}{*}{$\begin{array}{c}\Lambda \mathrm{m}_{2} \\
\left(\mathrm{ohm}^{-1} \mathrm{~cm}^{2} \mathrm{~mol}^{-1}\right)\end{array}$} \\
\hline & & & $\mathrm{C}$ & $\mathbf{H}$ & $\mathbf{N}$ & \\
\hline $\begin{array}{c}\mathrm{C}_{32} \mathrm{H}_{22} \mathrm{Cl}_{2} \mathbf{N}_{2} \mathrm{O}_{2} \\
\text { (iiia) White }\end{array}$ & 167 & 85 & $\begin{array}{l}71.63 \\
(71.51)\end{array}$ & $\begin{array}{c}4.22 \\
(4.13)\end{array}$ & $\begin{array}{l}5.62 \\
(5.21)\end{array}$ & - \\
\hline $\begin{array}{c}\mathrm{C}_{32} \mathrm{H}_{20} \mathrm{Cl}_{2} \mathrm{~N}_{2} \mathrm{O}_{2} \mathrm{Co}\left(\mathrm{H}_{2} \mathrm{O}\right)_{2} \\
\left(\mathrm{ivM}_{1}\right) \text { brown }\end{array}$ & $>250$ & 60 & $\begin{array}{c}61.23 \\
(61.14)\end{array}$ & $\begin{array}{c}3.10 \\
(3.18)\end{array}$ & $\begin{array}{c}4.73 \\
(4.45)\end{array}$ & 18.9 \\
\hline $\begin{array}{c}\mathrm{C}_{32} \mathrm{H}_{20} \mathrm{Cl}_{2} \mathrm{~N}_{2} \mathrm{O}_{2} \mathrm{Ni}\left(\mathrm{H}_{2} \mathrm{O}\right)_{2} \\
\left.(\mathrm{ivM})_{2}\right) \text { Light Yellow }\end{array}$ & $>250$ & 65 & $\begin{array}{c}60.73 \\
(60.56)\end{array}$ & $\begin{array}{c}3.82 \\
(3.15)\end{array}$ & $\begin{array}{c}4.28 \\
(4.41)\end{array}$ & 16.2 \\
\hline $\begin{array}{l}\mathrm{C}_{32} \mathrm{H}_{20} \mathrm{Cl}_{2} \mathrm{~N}_{2} \mathrm{O}_{2} \mathrm{Cd}\left(\mathrm{H}_{2} \mathrm{O}\right)_{2} \\
\left(\mathrm{ivM}_{3}\right) \text { White }\end{array}$ & $>250$ & 60 & $\begin{array}{c}56.45 \\
(56.30)\end{array}$ & $\begin{array}{c}2.79 \\
(2.93)\end{array}$ & $\begin{array}{c}4.52 \\
(4.10)\end{array}$ & 14.2 \\
\hline $\begin{array}{l}\mathrm{C}_{32} \mathrm{H}_{20} \mathrm{Cl}_{2} \mathrm{~N}_{2} \mathrm{O}_{2} \mathrm{Cu}\left(\mathrm{H}_{2} \mathrm{O}\right)_{2} \\
\left(\mathrm{ivM}_{4}\right) \text { Dark green }\end{array}$ & $>250$ & 62 & $\begin{array}{c}60.04 \\
(60.70)\end{array}$ & $\begin{array}{c}3.08 \\
(3.16)\end{array}$ & $\begin{array}{c}4.03 \\
(4.43)\end{array}$ & 18.3 \\
\hline
\end{tabular}

Table 2:-

\begin{tabular}{|c|c|c|c|c|c|c|}
\hline \multirow{2}{*}{$\begin{array}{l}\text { Compound } \\
\text { (Colour) }\end{array}$} & \multirow{2}{*}{$\begin{array}{l}\text { M.pt. } \\
\left({ }^{0} \mathrm{C}\right)\end{array}$} & \multirow{2}{*}{$\begin{array}{c}\text { Yield } \\
(\%)\end{array}$} & \multicolumn{3}{|c|}{ Found (Calc.) \% } & \multirow{2}{*}{$\begin{array}{c}\Delta \mathrm{m}_{2} \\
\left(\mathrm{ohm}^{-1} \mathrm{~cm}^{2} \mathrm{~mol}^{-1}\right) \\
\end{array}$} \\
\hline & & & $\mathrm{C}$ & $\mathbf{H}$ & $\mathbf{N}$ & \\
\hline $\begin{array}{l}\mathrm{C}_{34} \mathrm{H}_{26} \mathbf{N}_{2} \mathrm{O}_{2} \\
\text { (iiib) White }\end{array}$ & 156 & 79 & $\begin{array}{l}82.16 \\
(82.20)\end{array}$ & $\begin{array}{c}5.30 \\
(5.24)\end{array}$ & $\begin{array}{c}5.55 \\
(5.61)\end{array}$ & - \\
\hline $\begin{array}{c}\mathrm{C}_{34} \mathrm{H}_{24} \mathrm{~N}_{2} \mathrm{O}_{2} \mathrm{Co}\left(\mathrm{H}_{2} \mathrm{O}\right)_{2} \\
\left(\text { ivM }_{5}\right) \text { Brown }\end{array}$ & $>250$ & 68 & $\begin{array}{l}69.44 \\
(69.28) \\
\end{array}$ & $\begin{array}{c}4.18 \\
(4.07)\end{array}$ & $\begin{array}{c}4.65 \\
(4.75)\end{array}$ & 19.6 \\
\hline $\begin{array}{c}\mathrm{C}_{34} \mathrm{H}_{24} \mathrm{~N}_{2} \mathrm{O}_{2} \mathrm{Ni}\left(\mathrm{H}_{2} \mathrm{O}\right)_{2} \\
\left(\mathrm{ivM} \mathbf{M}_{6}\right) \text { Yellow }\end{array}$ & $>250$ & 62 & $\begin{array}{c}69.11 \\
(69.01)\end{array}$ & $\begin{array}{c}4.10 \\
(4.02)\end{array}$ & $\begin{array}{c}4.35 \\
(4.58)\end{array}$ & 16.9 \\
\hline $\begin{array}{c}\mathrm{C}_{34} \mathrm{H}_{24} \mathrm{~N}_{2} \mathrm{O}_{2} \mathrm{Cd}\left(\mathrm{H}_{2} \mathrm{O}\right)_{2} \\
\quad\left(\text { ivM }_{7}\right) \text { White }\end{array}$ & $>250$ & 61 & $\begin{array}{l}63.70 \\
(63.75)\end{array}$ & $\begin{array}{c}3.72 \\
(3.75)\end{array}$ & $\begin{array}{c}4.28 \\
(4.37)\end{array}$ & 14.5 \\
\hline $\begin{array}{c}\mathrm{C}_{34} \mathrm{H}_{24} \mathrm{~N}_{2} \mathrm{O}_{2} \mathrm{Cu}\left(\mathrm{H}_{2} \mathrm{O}\right)_{2} \\
\left(\mathrm{ivM}_{8}\right) \text { Algae green }\end{array}$ & $>250$ & 60 & $\begin{array}{r}68.75 \\
(68.91)\end{array}$ & $\begin{array}{c}4.15 \\
(4.05)\end{array}$ & $\begin{array}{c}4.83 \\
(4.72)\end{array}$ & 19.8 \\
\hline
\end{tabular}


Table 3:-

\begin{tabular}{|c|c|c|c|c|}
\hline \multirow[t]{2}{*}{$\begin{array}{c}\text { Ligand/ } \\
\text { complexes }\end{array}$} & \multicolumn{3}{|c|}{$\begin{array}{l}\text { Electronic absorption bands and their assignments } \\
\qquad(\mathrm{nm})\end{array}$} & \multirow{2}{*}{$\begin{array}{l}\text { Magnetic } \\
\text { Moment } \\
\mu \text { eff, BM }\end{array}$} \\
\hline & $\pi \rightarrow \pi^{*}$ & $\mathrm{n} \rightarrow \pi^{*}$ & $\mathrm{~d} \rightarrow \mathrm{d}$ transition & \\
\hline $\begin{array}{l}\mathrm{C}_{32} \mathrm{H}_{22} \mathrm{Cl}_{2} \mathrm{~N}_{2} \mathrm{O}_{2} \\
\text { (iiiia) White }\end{array}$ & 280 & 375 & ---- & ---- \\
\hline $\begin{array}{c}\mathrm{C}_{32} \mathrm{H}_{20} \mathrm{Cl}_{2} \mathrm{~N}_{2} \mathrm{O}_{2} \mathrm{Co}\left(\mathrm{H}_{2} \mathrm{O}\right)_{2} \\
\left(\mathrm{ivM}_{1}\right) \text { brown }\end{array}$ & 275 & 355 & 483 & 4.50 \\
\hline $\begin{array}{c}\mathrm{C}_{32} \mathrm{H}_{20} \mathrm{Cl}_{2} \mathrm{~N}_{2} \mathrm{O}_{2} \mathrm{Ni}\left(\mathrm{H}_{2} \mathrm{O}\right)_{2} \\
\left(\text { ivM }_{2}\right) \text { Light Yellow }\end{array}$ & 285 & 371 & 465 & 3.11 \\
\hline $\begin{array}{l}\mathrm{C}_{32} \mathrm{H}_{20} \mathrm{Cl}_{2} \mathrm{~N}_{2} \mathrm{O}_{2} \mathrm{Cd}\left(\mathrm{H}_{2} \mathrm{O}\right)_{2} \\
\left(\mathrm{ivM}_{3}\right) \text { White }\end{array}$ & 288 & 371 & ---- & ---- \\
\hline 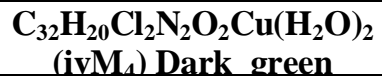 & 291 & 388 & 505 & 1.92 \\
\hline $\begin{array}{l}\mathrm{C}_{34} \mathrm{H}_{26} \mathrm{~N}_{2} \mathrm{O}_{2} \\
\text { (iiib) White }\end{array}$ & 286 & 395 & ---- & ---- \\
\hline $\begin{array}{l}\mathrm{C}_{34} \mathrm{H}_{24} \mathrm{~N}_{2} \mathrm{O}_{2} \mathrm{Co}\left(\mathrm{H}_{2} \mathrm{O}\right)_{2} \\
\left(\mathrm{ivM}_{5}\right) \text { Brown }\end{array}$ & 277 & 384 & 499 & 4.55 \\
\hline $\begin{array}{c}\mathrm{C}_{34} \mathrm{H}_{24} \mathrm{~N}_{2} \mathrm{O}_{2} \mathrm{Ni}\left(\mathrm{H}_{2} \mathrm{O}\right)_{2} \\
\left(\text { ivM }_{6}\right) \text { Yellow }\end{array}$ & 293 & 391 & 501 & 3.02 \\
\hline $\begin{array}{c}\mathrm{C}_{34} \mathrm{H}_{24} \mathrm{~N}_{2} \mathrm{O}_{2} \mathrm{Cd}\left(\mathrm{H}_{2} \mathrm{O}\right)_{2} \\
\left(\text { ivM }_{7}\right) \text { White } \\
\end{array}$ & 291 & 376 & ---- & ---- \\
\hline $\begin{array}{c}\mathrm{C}_{34} \mathrm{H}_{24} \mathrm{~N}_{2} \mathrm{O}_{2} \mathrm{Cu}\left(\mathrm{H}_{2} \mathrm{O}\right)_{2} \\
\left(\text { ivM }_{8}\right) \text { Algae green }\end{array}$ & 284 & 380 & 485 & 1.90 \\
\hline
\end{tabular}

\section{Biology:-}

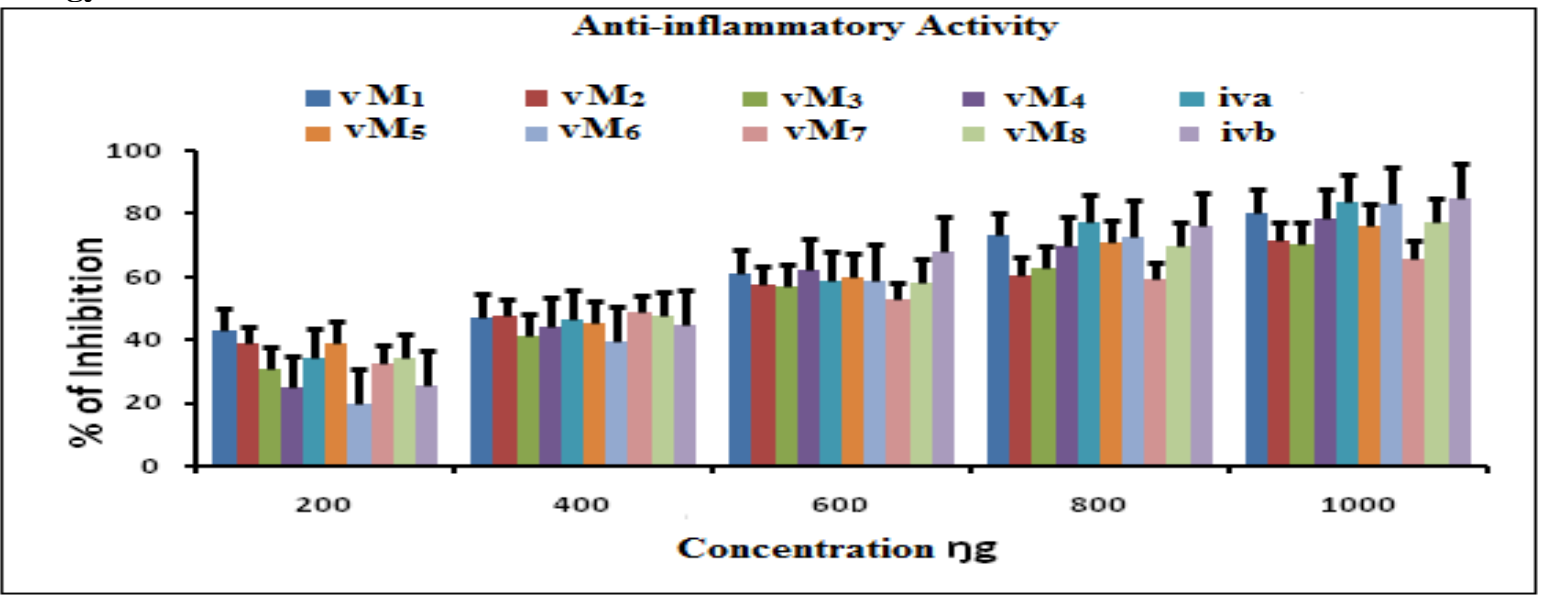

Figure 1:- Effect of Schiff-base on the activity of PLA 2

$\mathbf{v M}_{1}, \mathbf{v M}_{2}$ and $\mathbf{v M}_{3}$ have showed the maximum inhibition with IC50 value of $531 \mu \mathrm{g} / \mathrm{ml}, 539 \mu \mathrm{g} \mathrm{ml}$ and $547 \mu \mathrm{g} / \mathrm{ml}$ respectively which is followed by compounds $\mathbf{v} \mathbf{M}_{\mathbf{4}}$, iva, $\mathbf{v} \mathbf{M}_{5}, \mathbf{v} \mathbf{M}_{\mathbf{6}}, \mathbf{v} \mathbf{M}_{\mathbf{7}}, \mathbf{v} \mathbf{M}_{\mathbf{8}}$ and ivb Showed inhibition with IC50 value of $563 \mu \mathrm{g} / \mathrm{ml}, 578 \mu \mathrm{g} / \mathrm{ml}, 612 \mu \mathrm{g} / \mathrm{ml}, 638 \mu \mathrm{g} / \mathrm{ml}, 655 \mu \mathrm{g} / \mathrm{ml}, 671 \mu \mathrm{g} / \mathrm{ml}$ and $684 \mu \mathrm{g} / \mathrm{ml}$ respectively. All the compounds show almost complete inhibition at less than $1 \mu \mathrm{g} / \mathrm{ml}$. 
Table 4:- IC $_{50}$ Value of PLA2 inhibition by Schiff- base derivatives.

\begin{tabular}{|c|c|}
\hline Compounds & IC50 value $(\mu \mathrm{g} / \mathrm{ml})$ \\
\hline iva & 578 \\
\hline $\mathrm{vM}_{1}$ & 563 \\
\hline $\mathrm{vM}_{2}$ & 547 \\
\hline $\mathrm{vM}_{3}$ & 539 \\
\hline $\mathrm{vM}_{4}$ & 531 \\
\hline $\mathrm{ivb}$ & 684 \\
\hline $\mathrm{vM}_{5}$ & 671 \\
\hline $\mathrm{vM}_{6}$ & 655 \\
\hline $\mathrm{vM}_{7}$ & 638 \\
\hline $\mathrm{vM}_{8}$ & 612 \\
\hline
\end{tabular}

Table 5:- MIC values of Standard Antibiotics and Schiff- base derivatives in different micro-organisms.

\begin{tabular}{|c|c|c|c|c|c|}
\hline \multicolumn{6}{|c|}{$\begin{array}{c}\text { MIC }(\mu \mathrm{g} / \mathrm{mL}) \text { results } \\
\text { (Minimum inhibitory concentration) }\end{array}$} \\
\hline Compounds & $\begin{array}{c}\text { E.coli } \\
\text { (Gram - } \\
\text { ve) }\end{array}$ & $\begin{array}{c}\text { Listeria } \\
\text { monocytogenes } \\
\text { (Gram -ve) }\end{array}$ & $\begin{array}{c}\text { Stepotococcusepidermidis } \\
(\text { Gram +ve })\end{array}$ & $\begin{array}{c}\text { Staphylococcus } \\
\text { aureus } \\
\text { (Gram +ve) }\end{array}$ & $\begin{array}{l}\text { Candida } \\
\text { albicans } \\
\text { (Fungus) }\end{array}$ \\
\hline Gentamycin & 1.0 & 10 & 0.75 & 0.5 & \\
\hline Flucanazole & - & _- & - & - & $0.75 \mu \mathrm{g}$ \\
\hline iva & $11 . \overline{75} \mu \mathrm{g}$ & -- & $89 . \overline{86} \mu \mathrm{g}$ & ----- & $7.94 \mu \mathrm{g}$ \\
\hline $\mathrm{M}_{1}$ & $35 \mu \mathrm{g}$ & $15.01 \mu \mathrm{g}$ & $31.47 \mu \mathrm{g}$ & -------- & $9.9 \mu \mathrm{g}$ \\
\hline $\mathrm{M}_{2}$ & $14.18 \mu \mathrm{g}$ & $28.56 \mu \mathrm{g}$ & ------- & -------- & $18.63 \mu \mathrm{g}$ \\
\hline $\mathrm{M}_{3}$ & $5.35 \mu \mathrm{g}$ & -------- & -------- & -------- & ------ \\
\hline $\mathrm{M}_{4}$ & -------- & -------- & -------- & -------- & -------- \\
\hline ivb & $26.12 \mu \mathrm{g}$ & -------- & -------- & $55.70 \mu \mathrm{g}$ & -------- \\
\hline $\mathrm{M}_{5}$ & - - - --- & $7.16 \mu \mathrm{g}$ & $64.22 \mu \mathrm{g}$ & -------- & -------- \\
\hline $\mathrm{M}_{6}$ & -------- & $9.06 \mu \mathrm{g}$ & $10.54 \mu \mathrm{g}$ & $13.89 \mu \mathrm{g}$ & ------- \\
\hline $\mathrm{M}_{7}$ & $2.03 \mu \mathrm{g}$ & $19.27 \mu \mathrm{g}$ & $16.42 \mu \mathrm{g}$ & -------- & -------- \\
\hline $\mathrm{M}_{8}$ & -------- & -------- & -------- & $15.68 \mu \mathrm{g}$ & -------- \\
\hline
\end{tabular}

Antimicrobial activity:-

Compounds (iva, $\mathbf{v} \mathbf{M}_{1}$ to $\mathbf{v} \mathbf{M}_{4}$ and $\mathbf{i v b}, \mathbf{v} \mathbf{M}_{5}$ to $\mathbf{v} \mathbf{M}_{8}$ ) were tested in vitro for their antimicrobial activity against two Gram-positive and two Gram-negative bacterial strains. Commercial antibiotics such as gentamycin and flucanazole were used as standard drugs. The results were compared with standard drugs and depicted in Table 5. Among the Schiff- base derivatives $\left(\mathbf{v} \mathbf{M}_{1}\right.$ to $\mathbf{v M}_{\mathbf{4}}$ and $\mathbf{v} \mathbf{M}_{5}$ to $\mathbf{v} \mathbf{M}_{8}$ ) compound $\mathbf{v M}_{3}$ and $\mathbf{v} \mathbf{M}_{6}$ were showing maximum antibacterial activity than the other Schiff-base derivatives. $\mathbf{v M}_{\mathbf{2}}$ is potent against both Gram+ve and Gram -ve bacteria, only $\mathrm{vM}_{1}$ and $\mathrm{vM}_{2}$ of showed antifungal activity with the MIC of $9.9 \mu \mathrm{g}$ and $18.63 \mu \mathrm{g} / \mathrm{ml}$ respectively. $\mathbf{v M}_{4}$ did not show any microbial activity.

\section{Cell viability assay:-}

The cell viability assay reveals that the compounds $\mathbf{v} \mathbf{M}_{\mathbf{1}}$ to $\mathbf{M}_{\mathbf{3}}$ and $\mathbf{v} \mathbf{M}_{\mathbf{5}}$ to $\mathbf{M}_{\mathbf{7}}$ are found to be cyto protective in nature as the percent viability is greater than the control. The compound $\mathbf{M}_{\mathbf{4}}$ and ivb appears to be cytotoxic as the percent viability was lesser than the control. iva was found to be neither cytotoxic nor cytoprotective as the percent viability is similar to that of control. 
Table no 6: Percentage of viable cells after treated with Schiff- base derivatives

\begin{tabular}{|c|c|}
\hline & Cell viability \% \\
\hline Control & 30.84 \\
\hline $\mathrm{M}_{1}$ & 38.88 \\
\hline $\mathrm{M}_{2}$ & 48.97 \\
\hline $\mathrm{M}_{3}$ & 34.69 \\
\hline $\mathrm{M}_{4}$ & 39.21 \\
\hline $\mathrm{iva}$ & 30.95 \\
\hline $\mathrm{M}_{5}$ & 20.58 \\
\hline $\mathrm{M}_{6}$ & 48.33 \\
\hline $\mathrm{M}_{7}$ & 45.76 \\
\hline $\mathrm{M}_{8}$ & 15.55 \\
\hline $\mathrm{ivb}$ & 8.43 \\
\hline
\end{tabular}

DNA chelating activity of Schiff- base derivatives:-

\section{$\mathrm{C}$ iva $\mathrm{vM}_{1} \mathrm{vM}_{2} \mathrm{vM}_{3} \mathrm{vM}_{4}$}

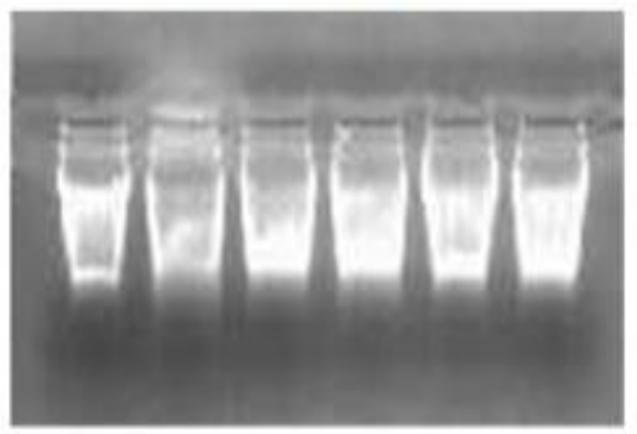

\section{C ivb vM5 vM6 $\mathrm{vM}_{7} \mathrm{vM}_{8}$}

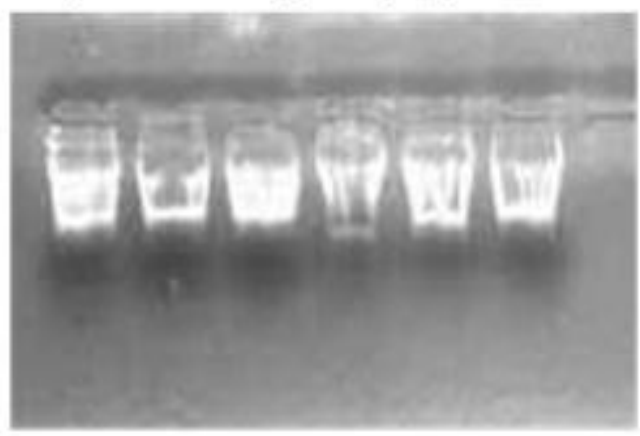

Figure 2:- Photographs showing the effects of Schiff-base derivatives on Calfthymus DNA

Gel electrophoresis picture is shown in figure 2. The photograph shows the bands with different band width and brightness compared to the control. The difference observed in the band width and intensity is the criterion for the evaluation of binding/cleavage ability of Schiff- base derivatives with calf thymus DNA. Figure2. Shows the bands with different light intensity compared to the control probably because of degradation of DNA by the compounds. There is significant binding of DNA in all lanes of $\mathbf{M}_{\mathbf{1}}$ to $\mathbf{M}_{\mathbf{4}}$ of scheme1 as there is increase in intensity in the DNA bands as shown in figure 2. The compound iva and $\alpha$ of ivb not only bound to the DNA but also degraded the DNA as it can be confirmed by the less intensity of the DNA. The remaining compounds are not involved in the degradation of the DNA, the same thing is also confirmed by cell viability assay.

\section{Conclusion:-}

The author has synthesized and characterized two new schiff-base ligands (iva, ivb) and eight metal complexes $\left(\mathbf{v} \mathbf{M}_{1}-\mathbf{M}_{\mathbf{8}}\right)$. These complexes have been characterized by utilizing the various physico-chemical methods. The molecular formulae of the complexes were calculated from the elemental analyses data and are in good agreement with theoretical values. The observed molar conductance of all the complexes in DMSO, magnetic susceptibility and spectral data confirm octahedral environment around the $\mathrm{M}(\mathrm{II})$ ions with $\mathrm{N}, \mathrm{O}$ as donor atoms and shows that they are non-electrolytes. The presence of coordinated water molecules in all the complexes has been further confirmed from IR. The mass spectrum of the complex confirms the proposed structure. Based on these evidences the following structures have been proposed for the complexes. A series of Schiff-base derivatives, iva, $\mathbf{M}_{\mathbf{1}} \mathbf{-} \mathbf{M}_{\mathbf{4}}$ and $\mathbf{M}_{\mathbf{5}^{-}}$ $\mathbf{M}_{8}$ of were screened for their DNA binding and chelating, anti-inflammatory and antimicrobial activity. Of the ten compounds tested $\mathbf{M}_{\mathbf{1}}$ and $\mathbf{M}_{\mathbf{2}}$ found to be potent antimicrobial compound with broad specificity, $\mathbf{M}_{\mathbf{6}}$ and $\mathbf{M}_{\mathbf{7}}$ showed only antibacterial activity. The compound iva and ivb were found to have potent DNA binding and chelating ability the remaining compounds were found to be cyto protective in nature but all the compounds proven to be potent 
anti-inflammatory compounds as they were showing more inhibition of $\mathrm{PLA}_{2}$ which is a pro enzyme to induce inflammation.

\section{References:-}

1. K. Y. ,A.Mayer, K.K.Cheung, Inorg, Chem, Acta. 1999, 285:223-232.

2. A.A.A. Emara, B.A. El-Sayed, et al. Spectrochimica Acta A. 2008, 69, 757-769.

3. H. Keypour, M. Shayesteh, et al. Molecu. Stru. 2013, 1032, 62.

4. A.A. El-Sherif, M.R. Shehata, et al. Spectrochimica Acta A. 2012, 96, 889.

5. Mei Wang, Hongjun Zhu, et al. J. Catal. 2003, 220, 392-398.

6. S. S. Djebbar, B. O Benanli, et al. Trans.Met. 1998, 23, 443-447.

7. Y. J. Hamada, Electron Transition. 1997, $44,1208$.

8. E. Colacio, M. Ghazi, et al. Inorg. Chem. 2000, 39, 2882.

9. A. Karaliota, O. Kresti, et al. J. Inorg. Biochem. 2001, 84, 33.

10. Asha M S, Bushra Begum A, et al. International Journal of Medicine and pharmaceutical Sciences. 2014, 4, 3, 41-52.

11. Asha M S, Bushra Begum A, et al. Chemical Science Review and Letter. 2014, 3, 11, 603-607.

12. B. S. Furniss, A. J. Hannaford, et al. in Vogel's Textbook of Practical Organic Chemistry. Pearson Education, 5th edition. 2006, 916

13. Geary W J, Coord Chem Rev. 1971, 71, 81.

14. J.A. Faniran, K.S. Patel, et al. J. Inorg. Nucl. Chem. 1974, 36, 1547.

15. Howlader M B H, Zakaria C M, et al. Jahangirnagar Univ J Sci. 2007, 3043.

16. 16. Sambandhan Karunakaran and Muthuswamy Kandaswamy, J. Chem. Soc. Dalton Trans. 1994, 1595, Dol: 10.

17. L.J. Bellamy, The Infrared Spectra of Complex Molecules. Second ed., Chapman \& Hall, Methuen, London, 1958, $1,17$.

18. J.R. Ferraro, Low-Frequency Vibrations of Inorganic and Coordination Compounds. Plenum press, New York, 1971, 978, 1.

19. K. Nakamoto, Infrared Spectra of Inorganic and Coordination Compounds. Part B, Fifth ed., Wiley Interscience, New York, 1971, 5.

20. D.P. Singh., K. Kumar., et al. J. Enzym, Inhib. Med. Chem. 2009, 24, 795.

21. A.M.A. Alaghaz, B.A. El-Sayed, et al. Mol. Struct. 2013, 1035, 83.

22. A.M.A. Alaghaz, H.A. Bayoumi, et al. Mol. Struct. 2013, 1035, 383.

23. I. Georgieva, N. Tredafilova, et al. Spectrochim. Acta A. 2006, 63, 403. 